Комшук Татьяна. Желудочковая система головного мозга в постнатальном онтогенезе у мужчин. В ходе морфометрического исследования магнитно-резонансных томограмм проанализировано соотношение размеров отдельных структур желудочковой системы у представителей мужского пола разных возрастных периодов. Изучены гендерные особенности и межполушарная асимметрия соответствующих показателей.

Ключевые слова: желудочковая система, I период зрелого возраста, пожилой возраст, мужчины, МРТ, морфометрия.

Komshuk Tetiana. Ventricular System of the Brain in Postnatal Ontogenesis in Men. Introduction into medical practice of new methods of neuroimaging - computer and magnetic resonance tomography, changed principles of diagnosis of brain morphological changes and opened new horizons in the study of its structure.

The aim of our study was to evaluate morphometric parameters of ventricular system of the brain on the results of MRI of men the period of mature and elderly.

Object and methods. A survey was conducted in the department of radiation diagnosis of clinical institution «Rivne Regional Clinical Hospital» on computer tomograph General Electric Nealthcare «SignaMRI 1,5T» and in the office of magnetic resonance tomography ща clinical institution «Lutsk Clinical Hospital» on computer tomograph Signa Profile Ce Medical Sistem - 1,5 Tl in standard anatomical planes (sagittal, frontal and axial).bMeasurements were carried out in people without visual signs of organic lesions of the brain and skull.

Brain imaging analyzes of men of different age groups, namely six tomograms (22-35 years) I mature period and 14 tomograms of elderly patients (61-74 years).

13 morphometric parameters of cerebrospinal fluid system of the brain were studied, namely the size of lateral, the III and IV brain ventricles and the length of aqueductus cerebri of men of different age groups.

During the study morphometric magnetic resonance tomograms analyzed the size ratio individual structures ventricular system of men of various ages. Studied gender characteristics and interhemispheric asymmetry of relevant indicators.

The study we found a significant increase in the size of the lateral ventricles in the age of men, namely length and width of the anterior horn of the lateral ventricle, both right and left; body width and length of the lateral ventricle posterior horn of the left side; the length of the lower horn; anteroposterior lateral ventricle size.

Found that the height of III and IV ventricles of the brain, the length of water pipe tends to gradually decrease with age.

It can be assumed that this age structural reorganization of the brain are caused by persistent metabolic changes that occur in the brain during the «aging».

Conclusions. Thus, there is reason to believe that presented intravital morphometric characteristic of the man brain of different age persons and identified on this basis criteria of age brain reorganization may be of interest to experts in the field of age anatomy, neurophysiology and neurosurgery, and for specialists of MRI-diagnostic can be an anatomical standard of ventricular system of the brain.

Key words: ventricular system, the man brain of different age, MRI, morphometry.

Стаття надійшла до редколегії 19.02.2016 p.

UDC 59:611.12:796.071

Alona Romaniuk

\title{
Special Aspects of Heart rate Variability in Track and Field Athletes and Players
}

The article was considered the features of autonomic regulation of heart rate in athletes. Modern level of sporting achievements puts forward the necessary conditions for study and evaluation of functional states and adaptive capacity of all body systems in interconnection, taking into account the autonomic regulation of the heart, the problem is actual enough. In the study were surveyed sportsmen playing sports and track and field athletes, using a method of HRV. It was studied the basic of time, spectral and HRV parameters (in R. Baevskyi) and established the predominant type of of vegetative regulation of cardiac activity. Athletes of team sport were characterized by a decrease in indexes of time than heart rate. he analysis of of spectral indexes has shown increasing values in track and field athletes. It was established predominant type of sympathetic autonomic regulation of the heart in sportsmen playing sports, and the track and field athletes found predominant type of parasympathetic autonomic regulation. Obtained results are confirm lowering mechanisms of self-regulation and activation energy centers metabolic for sportsmen playing sports. In track

(C) Romaniuk A., 2016 
and field athletes were established a higher level of physical fitness and note the decrease in activity of the central control loop.

Key words: heart rate variability, track and field athletes, players, sympathetic and parasympathetic parts of nervous system.

Introduction. It is well known that in living organisms everything can be regulated and it is impossible to evaluate a functional state of organism and its adaptation abilities without determining its regulation quality. Heart rate is governed by the hierarchical system of structures and mechanisms, including encephalon and endocardial levels. Analysis of heart rate variability is a method for evaluation regulating mechanisms of physiologic functions in a human body as well as total activity of regulating mechanisms, heart neurohumoral regulation, equilibration between sympathetic and parasympathetic parts of nervous system.

Nowadays heart rate variability (HRV) is one of the most widely used methods in human medicine and physiology. It is proved by numerous academic publications on studying special aspects of heart rate variability $[1 ; 10]$. This method is still advantageous as it enables to obtain new information of practical importance in a wide range of application. In addition to physiology these research and practice recommendations are no exception for sport physiology, sport medicine and other fields.

The current state of sport achievements puts forward demands to study and estimate functional states and adaptation abilities of all organism systems in interaction, to determine specific quality features and their performance in a particular sport.

According to the nature of regulating mechanisms, a level of physiological reserve and a physiological penalty of adaptation for main adaptive systems athlete's tolerance to training and competitive stress loads, sport results, maintenance of positive health progress are defined [7]. The network of organism adaptive systems includes the cardiovascular system. This is the most mobile system of an organism in adaptation processes of muscle loads and it provides the final sport outcome.

Estimating special aspects of heart rate variability parameters permits to make a scientific forecast of physical capacities, to handle a problem of selection for sport, to make a training regime more wellbalanced, to monitor and analyze athletes' functional state. However, it should be noted that the different orientation of a training process impacts differently on adaptation abilities.

In athletes with long duration of dynamic loads (endurance training) a portion of accidental effects on the pacemaker activity of the sinoatrial node reduced. Namely, the sinoatrial node becomes relatively independent from morphometric and hemodynamic parameters of cardiac performance $[3 ; 11]$.

The deeper interaction of heart rate variability parameters with heart morphometry and hemodynamics is observed in the group of athletes that develop speed and strength.

Taking into consideration the fact that evaluation of HRV measures is one of main parameters for studying adaptation abilities and it is a personal characteristic of athletes with different sport specialization profile, the research of interaction of these parameters is a challenging issue.

Scientific achievements in researching HRV of athletes are quite considerable $[1 ; 2 ; 5 ; 8]$, and still the issue of HRV special aspects for competitive sport and track and field athletes has not been fully investigated.

The objective of the research was to investigate special aspects of HRV parameters for competitive sport and track and field athletes.

Data For Study and Methods. 52 males took part in the study. All of them were athletes of different sport profile, aged 17-25. The athletes were in good health according to the data of somatic and psychoneurological examination. As to their sport profile they were divided into two groups: I groups athletes of team sport (basketball, volleyball, football) - players, II groups - track and field athletes (sprint, long-distance running, racewalking) - athletes. The athletes had Master of Sport qualification (MS) as well as athletic titles from III class to Candidate Master of Sports (CMS).

The number in each testing group was 26 sportsmen. The calculation of the selection scope was made with the help of programme unit Experimental design techniques in statistical package MedStat [4]. The experimental design allows to make an assessment of the selection scope before testing to see if it is sufficient to identify biologically significant effect with regard to power of the statistical test and test significance. The programme unit uses methods of selection scope evaluation to compare two frequencies and to compare two averages. We used a method of evaluation to compare two averages. During the 
computation of selection scope the significance level was $5 \%$ and power was $80 \%$. The standard deviation was 3,4 and the biologically significant effect equals 2 .

The statistical data processing was made using statistical package MedStat. Depending on data distribution (if they are subject to a normal distribution of values or different from a normal distribution of values) descriptive statistics, Student t-test, Spearman and Pearson correlation coefficient were used.

HRV records were made by means of a portable ECG recorder "CardioLab HRV», designed by «HAIMEDYKA». The state of the autonomic nervous system under HRV analysis was investigated in the conditions of relative rest - determination of vegetative profile or general vegetative tonus. The duration of a HRV record was 300 seconds. A monitoring HRV record with the purpose of HRV analysis was made in the morning, 1,5-2 hours after the meal, in a quiet darkened room with regular temperature $-20-22^{\circ}$ C. A record was made in the supine position with quiet breathing: an experimental subject didn't cough, swallow, talk, didn't take deep breaths.

Electrodes of main leads were put in compliance with the common method: red $-\mathrm{R}$ (on the right arm), yellow - L (on the left arm), green $-\mathrm{F}$ (left leg), black $-\mathrm{N}$ (right leg). Electrodes were placed on inner side of right and left forearms and the lower third of left and right shins. Making sure in stability and quality of ECG registration, we started recording it in a computer memory. Various artifacts due to network guidance, muscular tremor, fault contacts of electrodes with skin, uneasy behaviour of a subject and other factors were removed in compliance with the directions to the ECG recorder.

Results and their Interpretation. The core of HRV study is measuring time intervals between R-deflections (RR-intervals, cardio intervals) at electrocardiogram tracing (ECG) and making up a rhythmogram based on them with the following analysis with the help of various methods.

The obtain results of HRV parameters that were different from normal distribution were processed by distribution-free methods of Shapiro-Wilk test statistics. Variables SDNN, RMSSD, pNN50, CV, applying for a direct quantitative HRV assessment within the study interval for players are presented in table 1.

SDNN represents total variability of RR-intervals values for the study interval. It is one of main HRV variables and reflects the overall condition of regulating mechanisms (activity of the autonomic nervous system) [10]. The SDNN value for players is $57 \mathrm{~ms} \pm 4,346$ and for track and field athletes $-70,85 \mathrm{~ms} \pm$ 27,93 (fig. 1).

Table 1

Values of Heart Rate Variability for Athletes of Team Sport and Track and Field Athletes

\begin{tabular}{|c|c|c|}
\hline Indexes & Athletes of Team Sport & Track and Field Athletes \\
\hline SDNN & $57 \pm 4,34$ & $70,85 \pm 27,93$ \\
\hline RMSSD & $35 \pm 3,68$ & $55,73 \pm 29,83$ \\
\hline pNN50 & $13,5 \pm 3,33$ & $28 \pm 5,68$ \\
\hline CV & $7 \pm 0,50$ & $7,769 \pm 2,405$ \\
\hline Mo & $805,8 \pm 107,1$ & $850 \pm 165,5$ \\
\hline AMo & $34,96 \pm 8,253$ & $29,5 \pm 3,87$ \\
\hline RV & $254 \pm 14,04$ & $279,8 \pm 81,48$ \\
\hline SI & $89,15 \pm 36,06$ & $54 \pm 30,76$ \\
\hline TP & $3230,5 \pm 641,4$ & $62,96 \pm 18,73$ \\
\hline LFnorm & $68,42 \pm 11,05$ & $37,04 \pm 18,73$ \\
\hline HFnorm & $31,58 \pm 11,05$ & $1060,5 \pm 292,6$ \\
\hline VLF & $1089 \pm 447,1$ & $1,515 \pm 0,83$ \\
\hline LF/HF & $2,547 \pm 1,22$ & $1737,5 \pm 487,3$ \\
\hline LF & $1295 \pm 196,3$ & $1007 \pm 459,4$ \\
\hline HF & $556,5 \pm 169,7$ & $2,715 \pm 0,98$ \\
\hline IC & $4,04 \pm 0,68$ & $14,77 \pm 5,771$ \\
\hline HRV & $12,5 \pm 1,01$ & $886,5 \pm 161,2$ \\
\hline mRR & $833,3 \pm 95,97$ & $69,5 \pm 3,43$ \\
\hline HR & $72,92 \pm 8,28$ & \\
\hline & & \\
\hline
\end{tabular}




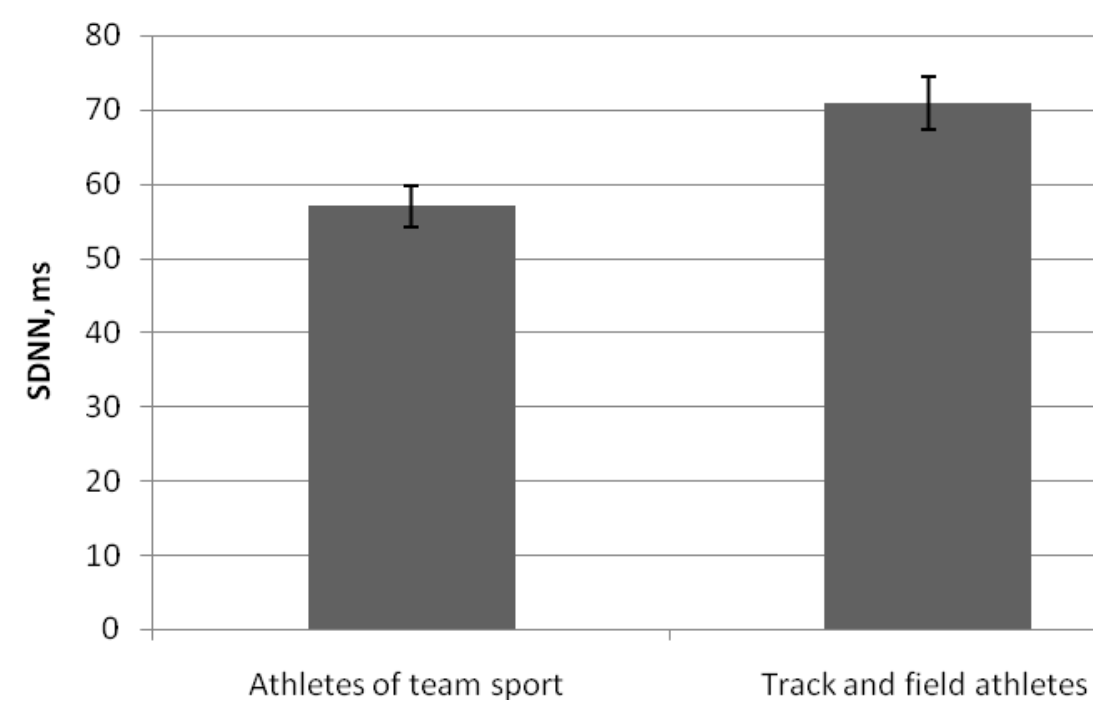

Fig. 1. Index of SDNN in Athletes of Team Sport and Track and Field Athletes

The obtain data are indicative of a SDNN value reduction for players and a boost of sympathetic regulation that suppresses the autonomic circle activity. In contrast, field and track athletes have increased values correspondingly and this result can be linked to both sympathetic and parasympathetic effects on heart rate. Considering the fact that our study deals with and analyzes short term recordings, we may suggest that this increase in SDNN values is associated with a boost of the autonomic regulation, i.e. increasing impact of breathing on heart rate.

The square root of the mean of the squares of the successive differences between adjacent NNs (RMSSD) is a description of activity of parasympathetic division of the autonomic regulation [6]. This value for players and track and field athletes is within normal limits. However, it should be noted that there is a decrease in RMSSD values for players in comparison with track and field athletes.

The predominance of parasympathetic pathway in regulation over sympathetic one becomes apparent in the group of team sport athletes. Decrease of pNN50 value was registered in this group of athletes. For track and field athletes pNN50 value is slightly larger that for competitive sport athletes (table 1).

HRV temporal rate CV (coefficient of variation of all range of cardio intervals) is a norm-based score of regulation cooperative effect [6; 9]. Having used Shapiro-Wilk test (W) through the distribution for normality its deviation was defined, $\mathrm{W}=0,805$ at $\mathrm{p} \leq 0,01$. Similar rates of CVs were found for the two groups of athletes.

Using geometric methods for HRV we analyzed such variables as: AMo, Mo, RV, SI. Mo (mode) is values of RR-intervals that are most frequent and corresponds to the most probable performance level of regulation systems $[2 ; 12]$.

Mo figures for players are slightly higher than for athletes (table 1). Appropriately AMo rates, i.e. the number of RR intervals, corresponding to mode rates, in percentage terms \% to the selection scope is higher for players. It shows stabilizing effect of centralized governance of heart rate conditioned basically by activation degree of the sympathetic nervous system.

The variation range demonstrates the diversity of cardio intervals values in the studied dynamic band [5; 8]. In terms of physiology RV means a maximum amplitude of the ANS regulating effects. This index is higher for players (table 1).

SI is an index of regulatory systems tension. It is a very sensitive indicator of ANS condition that reflects the control heart rate centralization degree and describes the activity of ANS sympathetic pathway. It is widely used in sports medicine, occupational physiology, space researches as well as in clinical experience and other areas [12; 16]. For athletes the SI normal range is 50-150 conditional units. In our research this index value is higher for team players in comparison with track and field athletes (table 1). The lower regulatory systems tension is, the higher a training and fitness condition level is. Taking this fact into consideration track and field athletes had a higher training and fitness condition level. 
Spectral analysis of heart rate variability enables to analyze spectral density of oscillations power and give information on intensity distribution depending on vibration frequency [9]. Considering their widespread application we used the following indicators such as: TP, LFnorm, HFnorm, VLF, LF/HF, LF, HF, IC.

TP refers to a total capacity of all spectral components or the full frequency spectrum that is descriptive of HRV. The capacity in the range from 0,003 to $0,40 \mathrm{~Hz}$ reflects a total impact of vegetative interaction on heart rate and has the same physiological meaning as SDNN. TP rate is lower for team players in comparison with track and field athletes; it denotes mobilization of human functional reserve for players and activation of deeper levels of control among athletes.

$\mathrm{HF}$ is the HRV intensity of high-frequency waves in the frequency range $0,15-0,40 \mathrm{~Hz}$. The output within this range is mainly connected with respiratory movements and reflects vagus control of heart rate (the parasympathetic activity) $[1 ; 7 ; 15]$. Indexes of this indicator are lower for players than for athletes. It means the autonomous circle of control and a fall in activity of self-regulation mechanisms for players.

In turn LF is the intensity of low-frequent waves within the range of $0,04-0,15 \mathrm{~Hz}$. These waves are of mixed origin. Changes in both sympathetic (mainly) and parasympathetic activity influence the capacity within this range. There are lower values of this indicator in the group of players in comparison with athletes and it points at a fall in sympathetic activity of vasomotor center. It involves the central circle control.

VLF is linked to slow waves in the range $0,003-0,04 \mathrm{~Hz}$. There are some physiological factors that have effect on them such as renin-angiotensin system, catecholamine concentration in plasma, thermal control system and others. The index of this indicator is higher for players and proves the evidence of activation of energy and metabolism centers.

$\mathrm{LF} / \mathrm{HF}$ is a sympathovagal index that is characteristic of correlation or equilibration of sympathetic and parasympathetic influence on heart rate. This value is higher in the group of players and describes an activity boost of central control circle. Slightly lower figures are observed among athletes and it denotes a decline in the activity of central circle control.

LFnorm, HFnorm are capacities in the range of low and high frequencies in normalized units. They describe relative contribution of sympathetic and parasympathetic influence on heart rate [9]. Between values of LFnorm, HFnorm in the two groups of athletes no distinguishing deviation was found.

IC (an index of centralization) reflects predominance of non-respiratory components of sinus arrhythmia over respiratory ones or balance between autonomic and central control management of heart rate regulation. This index provides analysis of subcortical cardiovascular center activity related to the activity of highest control levels $[12 ; 14]$. This index value is higher in players and shows growth regulating activity of the central circle control.

Another important index is frequency of heart beats (HR). HR value is lower in athletes in comparison with players as a result of dominance of parasympathetic influence in regulating mechanisms for athletes.

To determine strong interaction between HRV indices we applied Pearson's correlation for arrangement of values that are not different from normal and Spearman's correlation for arrangement of values different from normal. Correlation coefficient $r$ can have value from -1 to +1 . The stronger correlation is, the larger value of $r$ is.

In our study with help of Pearson correlation we found a positive correlation in athletes between indices $\mathrm{CV}$ and SDNN, $r=0,927$; RV and SDNN, $r=0,935$; Mo та mRR, $r=0,986$; $\mathrm{CV}$ and RV, $r=0,900$; RV та $\mathrm{HRV}, \mathrm{r}=0,910$. By virtue of the fact that many HRV indices are correlated with each other, we focused on two of them: RV (Rate Variability) and SDNN. The first indicator describes dominance of parasympathetic impact, respectively a RV increase is correlated with SDNN, and this figure increase is a descriptor of predominance of the parasympathetic nervous system influence.

With the help of Spearman's correlation $[9 ; 13]$ the following positive interactions were found in the same group of athletes such as SI and TP, $r=0,981$; SI and AMo, $r=0,970 ; \mathrm{HF}$ and $\mathrm{pNN} 50, \mathrm{r}=0,955$, and also there are some negative interactions of AMo and TP, $r=-0,960$.

Using Pearson's correlation the following negative correlation relationships were determined in players such as: $\mathrm{mRR}$ and $\mathrm{HR}, \mathrm{r}=-0,991 ; \mathrm{HR}$ and Mo, $\mathrm{r}=-0,963$. Negative correlations are indicative of the fact that if one index lowers the other grows. The functioning level of cardiovascular system is characterized by index $\mathrm{mRR}$, i.e. while its reducing frequency of heart beats HR grows.

Positive correlations were defined between $\mathrm{mRR}$ and Mo, $r=0,973$; SI and AMo, $r=0,919$. With the help of Spearman correlation the following positive relations were found: pNN50 and RMSSD, $r=0,969$; 
TP and SDNN, $r=0,993$. As pNN50 and RMSSD fluctuate simultaneously and unidirectionally, hence the strong positive relationships of these indicators were determined in players and it implies the parasympathetic pathway predominance of the autonomic NS.

The strong positive correlation between indicators TP and SDNN was also specified, the explanation of which can be their similar traits. It should be pointed out that TP describes only periodic processes unlike SDNN values, that is why it is advisable to take these two indices as a whole in HRV assessment.

From this perspective therefore the assessment of heart rate variability permits to obtain required data about a functional condition of an athlete, to estimate the training process and find some ways of its improvement.

Conclusions and Future Perspectives. The predominance of sympathetic regulation was determined in team sport players. Intensity values of high-frequency waves for heart rate variability are statistically lower in comparison with track and field athletes and it implies an activity reduction of self regulation mechanisms and an activation of energy and metabolism centers.

The track and field athletes show the predominance of parasympathetic regulation over sympathetic, a higher condition level of training and fitness. The reduced activity of the central circle control was fixed.

The sportsmen in both groups were marked by positive and negative correlations between values of heart rate variability. The positive correlation between RV and SDNN suggests a dominant impact of the parasympathetic nervous system in track and field athletes. The negative correlation between mRR and HR in team sport players is a descriptor of cardiovascular system functioning, the mRR reduction results in heart rate increase.

The prospects for future research are to study special aspects of heart rate variability in team sport players and track and field athletes with various degrees of personal and state anxiety. Another direction is examining special aspects of reaction cortical activity in athletes with different types of the autonomic regulation.

\section{Sources and Literature}

1. Бань А. С. Использование вегетативного показателя для оценки вариабельности ритма сердца спортсменов игровых видов спорта / А. С. Бань, Г. М. Загородный, О. В. Петрова // Современные проблемы реабилитации и спортивной медицины : материалы Республиканской науч.-практ. конф., посвященной 50-летию каф. мед. реабилитации УО «ГрГМУ». - Гродно, 2012. - С. 29-33.

2. Гавриш И. В. Вариабельность сердечного ритма в оценке физической формы у квалифицированных спортсменов / И. В. Гавриш // Адаптация биологических систем к естественным и экстремальным факторам среды : материалы III Междунар. науч.-практ. конф.. - Челябинск, 2010. - С. 226-229.

3. Коробейников Г. В. Вариабельность ритма сердца как физиологический механизм адаптации к условиям напряженной мышечной деятельности / Г. В. Коробейников, А. А. Приймаков // Вестник Балтийской педагогической академии. - 2004. - Вип. 54. - С. 19-25.

4. Лях Ю. Е. Основы компьютерной биостатистики: анализ информации в биологии, медицины и фармации статистическим пакетом MadStat / Ю. Е. Лях, В. Г. Гурьянов, В. Е. Хоменко, О. А. Панченко. - Донецк, 2006. $-211 \mathrm{c}$.

5. Машин В. А. Зависимостьпоказателейвариабельности сердечного ритма от средней величины R-R интервалов / В. А. Машин // Российский физиологический журнал им. И. М. Сеченова, 2002. - Т. 88, № 7. - С. 851-855.

6. Михайлов В. М. Вариабельность ритма сердца. Опыт практического применения / В. М. Михайлов. Иваново, 2000. - 200 с.

7. Питкевич Ю. Э. Вариабельность сердечного ритма / Ю. Э. Питкевич // Проблемы и здоровья в экологии. - 2010. - № 4 (26). - С. 101-106.

8. Попов В. В. Вариабельность сердечного ритма: возможности применения в физиологии и клинической медицины / В. В. Попов, Л. Н. Фрицше // Український медичний часопис. - 2006. - № 2 (52). - С. $24-31$.

9. Рагозин А. Н. Информативность спектральных показателей вариабельности сердечного ритма / А. Н. Рагозин // Вестник аритмологии. - 2001. - № 22. - С. 37-40.

10. Ткачук В. Г. Исследование функциональных резервов сердечно-сосудистой системы у спортсменов в процессе соревновательной деятельности с использованием частотного и фрактального методов / В. Г. Ткачук, С. Н. Битко // Педагогіка, психологія та медико-біологічні проблеми фізичного виховання та спорту. - 2010. - № 5. - С. 145-147.

11. Хаспекова Н. Б. Диагностическая информативность мониторирования вариабельности ритма сердца / Н. Б. Хаспекова // Вестник аритмологии, 2003. - № 32. - С. 15-23. 
12. Яблучанский Н. И. Вариабельность сердечного ритма / Н. И. Яблучанский, А. В. Мартыненко. Харьков : [б. и.], 2013. - $131 \mathrm{c}$

13. Garcia-Tabar, Ibai; Llodio, Iñaki; Sánchez-Medina, Luis; Ruesta, Maite; Ibañez, Javier; Gorostiaga, Esteban M. Heart rate based prediction of fixed blood lactate thresholds in professional team-sport players // Journal of Strength\&Conditioning Research. - April 03. - 2015. - DOI: 10.1519/JSC.0000000000000957.

14. Lucas A. Pereira Nakamura Assessing. Shortened Field-Based Heart Rate Variability Data Acquisitionin Team-Sport Athletes / A. Lucas Pereira [et al.], 2015, DOI [Elektronik resourse]. - Mode of access : http://dx.doi.org/10.1123/ijspp.2015-0038.

15. Vanessa Pereirada Silva B. S., Natacha Alvesde Oliveira M. Sc., Heitor Silveira M. Sc., Roger Gomes Tavares Mello D. Sc. And Andrea Camaz Deslandes D. S. Heart Rate Variability Indexesas a Markerof Chronic Adaptationin Athletes: A Systematic Review / Vanessa Pereirada Silva B. S. [et al.] // Annals of Noninvasive Electrocardiology. - March 2015. - Vol. 20. - Issue 2. - P. 108-118.

16. Vincent Pichot, Frédéric Roche, Jean-Michel Gaspoz, Franck Enjolras, Anestis Antoniadis, Pascal Minini, FrédéricCostes, Thierry Busso, Jean-René Lacour, and Jean Claude Barthélémy. Relation between heart rate variability and training load in middle-distance runners / Vincent Pichot [et al.] // Medicine \& Science in sports \& exercise. -2000 . - P. 1729-1736.

Романюк Альона. Аналіз показників варіабельності серцевого ритму в спортсменів-ігровиків та легкоатлетів. Зважаючи на той факт, що оцінка показників варіабельності серцевого ритму є одним 3 основних показників вивчення адаптаційних можливостей, а також індивідуальною характеристикою спортсменів різної спортивної спеціалізації, у цій статті досліджуємо питання вивчення взаємозв'язків цих показників. Ураховуючи те, що науковий доробок щодо варіабельності серцевого ритму в спортсменів $€$ доволі значним, водночас простежуємо, що залишається не вивченим питання особливостей варіабельності серцевого ритму саме в спортсменів ігрових видів спорту та легкоатлетів. У ході дослідження нами встановлено, що в спортсменівігровиків виявлено переважання симпатичної ланки регуляції. Значення потужності високочастотних коливань варіабельності серцевого ритму статистично нижче, порівняно з легкоатлетами, що засвідчує зниження активності механізмів саморегуляції та активації центрів енергометаболічного обміну. Щодо результатів дослідження в спортсменів-легкоатлетів, то виявлено переважання парасимпатичної ланки регуляції над симпатичною. Вони характеризувалися вищим рівнем фізичної тренованості. Також установлено зменшення активності центрального контуру управління. У спортсменів обох груп відзначено позитивні й негативні кореляційні взаємозв'язки між показниками варіабельності серцевого ритму. Позитивний кореляційний зв'язок ВАР і SDNN указує на переважання впливу парасимпатичного відділу вегетативної нервової системи в спортсменівлегкоатлетів. Негативний кореляційний зв'язок між $\mathrm{mRR}$ та HR у спортсменів ігрових видів спорту характеризує функціонування серцево-судинної системи. Зниження $\mathrm{mRR}$ призводить до збільшення частоти серцевих скорочень

Ключові слова: варіабельність серцевого ритму, спортсмени-ігровики, спортсмени-легкоатлети, симпатичний та парасимпатичний типи вегетативної регуляції.

Романюк Алена. Анализ вариабельности сердечного ритма в спортсменов-игровиков и легкоатлетов. Учитывая тот факт, что оценка показателей вариабельности сердечного ритма является одним из основных показателей изучения адаптационных возможностей, а также индивидуальной характеристикой спортсменов различной спортивной специализации, в этой статье рассматриваем вопрос изучения взаимосвязей этих показателей. Учитывая то, что научный потенциал по изучению вариабельности сердечного ритма в спортсменов довольно значительный, наблюдаем в то же время, что остается неизученным вопрос особенностей вариабельности сердечного ритма именно у спортсменов игровых видов спорта и легкоатлетов. В ходе исследования нами установлено: у спортсменов-игровиков преобладает симпатическое звено регуляции. Значение мощности высокочастотных колебаний вариабельности сердечного ритма является статистически ниже, по сравнению с легкоатлетами, что свидетельствует о снижении активности механизмов саморегуляции и активации центров энергометаболического обмена. По результатам исследования у спортсменов-легкоатлетов установлено преобладание парасимпатического звена регуляции над симпатическим. Легкоатлеты характеризовались высоким уровнем физической тренированности. Также установлено уменьшение активности центрального контура управления. У спортсменов обеих групп отмечали положительные и отрицательные корреляционные взаимосвязи между показателями вариабельности сердечного ритма. Положительная корреляционная связь ВАР и SDNN указывает на преобладание влияния парасимпатического отдела вегетативной нервной системы у спортсменов-легкоатлетов. Отрицательная корреляционная связь между $\mathrm{mRR}$ и $\mathrm{HR}$ у спортсменов игровых видов спорта характеризует функционирование сердечно-сосудистой системы. Снижение $\mathrm{mRR}$ приводит к увеличению частоты сердечных сокращений.

Ключевые слова: вариабельность сердечного ритма, спортсмены-игровики, спортсмены-легкоатлеты, симпатичный и парасимпатический типы вегетативной регуляции.

Стаття надійшла до редколегії 11.02.2016 p. 